\title{
Keanekaragaman jenis dan karakteristik habitat nyamuk Anopheles spp. di Desa Datar Luas, Kabupaten Aceh Jaya, Provinsi Aceh
}

\author{
Species diversity and habitat characteristic of Anopheles spp. \\ in Datar Luas Village, Aceh Jaya Regency, Aceh Province \\ Riski Muhammad*, Susi Soviana, Upik Kesumawati Hadi \\ Program Studi Parasitologi dan Entomologi Kesehatan, Institut Pertanian Bogor \\ Jalan Agatis Kampus IPB Dramaga, Bogor 16680
}

(diterima Juli 2013, disetujui April 2014)

\begin{abstract}
ABSTRAK
Malaria merupakan penyakit tular vektor yang masih menjadi masalah kesehatan masyarakat di Indonesia. Upaya pengendalian telah dilakukan program pencegahan dan pengendalian penyakit tular vektor, tetapi belum bisa maksimal. Penyebab belum maksimalnya upaya pengendalian tersebut antara lain karena kurangnya pemahaman mengenai spesies vektor penyakit ini. Penelitian ini bertujuan untuk mempelajari keanekaragaman nyamuk, kepadatan dan perilaku nyamuk Anopheles, dan menganalisis peta karakteristik habitat perkembangbiakan larva Anopheles di Desa Datar Luas, Kecamatan Krueng Sabee, Kabupaten Aceh Jaya. Penangkapan nyamuk dilakukan dengan menggunakan metode human landing collection di dalam dan di luar rumah dari pukul 18:00-06:00 WIB. Selain itu, dilakukan pula pengumpulan larva dan penandaan titik koordinat pada habitat perkembangbiakan potensial. Hasil penelitian menemukan 11 spesies Anopheles yang didominasi oleh spesies An. kochi 45,9\%. An. kochi merupakan spesies dominan dengan aktivitas mengisap darah tertinggi dan ditemukan pada pukul 00:00-01:00 WIB. Berdasarkan jenis habitat larva Anopheles, spesies tertentu memiliki kecenderungan terhadap tipe habitat tertentu, sebagai contoh An. letifer banyak ditemukan di kolam, An. barumbrosus dan An. kochi ditemukan di genangan air hujan.
\end{abstract}

Kata kunci: Anopheles, kepadatan nyamuk, malaria, perindukan larva

\begin{abstract}
Malaria is a mosquitoe borne disease which still holds an impact position in public health sector in indonesia. The aims of this research are to study the diversity, density and behaviour of Anopheles, mapping its larvae habitat, and to measure the knowledge, attitudes and practices of the community in malaria endemic area at Datar Luas Village, Sub District Krueng Sabee, Aceh Jaya Regency. Mosquitoe trapping was done by landing collection inside and outside the house from 06:00 pm to 06:00 am WIB. In addition, larvae were collected and the coordinates of potential larva habitats were marked. There were eleven spesies of Anopheles, which were $45.9 \%$, An. barbirostris and An. minimus 8.1\%, An. maculatus, An. letifer, An. teselatus, An. sinensis, An. vagus, An. separatus 5.4\%, An. sundaicus and An. subpictus $2.7 \%$. The highest blood feed activity of An. kochi happened on 00:00-01:00 am WIB, An. minimus and An. barbiostris on 01:00-02:00 a.m WIB. There were four types of larvae i.e. pond, rain pudlles, marshes, and old well. An. letifer was found in pond, $A n$. barumbrosus and An. kochi were in rain puddles, An. kochi, An. aconitus, An. vaguswere in them arshes, and An. separatuswas in old well.
\end{abstract}

Key words: Anopheles, breeding place, density of mosquitoe, malaria

\footnotetext{
*Penulis korespondensi: Riski Muhammad. Program Studi Parasitologi dan Entomologi Kesehatan, Institut Pertanian Bogor

Jalan Agatis Kampus IPB Dramaga, Bogor 16680

Tel: 081360137490, Email : riski_4420@ymail.com
} 


\section{PENDAHULUAN}

Malaria merupakan salah satu penyakit tular vektor yang menjadi masalah kesehatan masyarakat di Indonesia. Hampir 50\% penduduk berisiko terjangkit penyakit ini dengan insiden pada ibu hamil berkisar 7-24\%, bergantung pada tingkat endemisitas suatu daerah (Kemenkes RI 2011). Nyamuk merupakan kelompok serangga yang paling banyak menimbulkan masalah kesehatan masyarakat. Kondisi ini disebabkan oleh keanekaragaman, distribusi, populasi dan banyaknya spesies nyamuk yang berperan sebagai pengganggu dan vektor penyakit (Becker et al. 2003).

Berdasarkan nilai annual parasite incidence (API), angka penularan penyakit malaria di Aceh Jaya masih tinggi karena di atas $1 \%$. Terjadi fluktuasi API, yaitu 5,97\% di tahun 2007, 10,78\% tahun 2008, dan 4,04\% tahun 2009. Di tahun 2010, API kembali mengalami peningkatan yang signifikan sebesar 13,24\% dan kembali menurun di tahun 2011 menjadi 1,370\% (Dinkes. Prov. Aceh 2011).

Desa Datar Luas merupakan salah satu desa di Kecamatan Krueng Sabee, Kabupaten Aceh Jaya yang termasuk wilayah endemis malaria. Kasus malaria di desa ini masih tinggi. Kecamatan Krueng Sabee memiliki API dari tahun 2010-2011 sebesar $62,79 \%$ dan mengalami penurunan 7,85\%, sedangkan API di Desa Datar Luas dari tahun 2010-2011 masing-masingnya sebesar 127,1\%, dan 2,27 (Dinkes. Prov. Aceh 2011).

Sehubungan dengan insiden malaria yang tinggi di Desa Datar Luas dan ditemukannya berbagai habitat perkembangbiakan yang potensial bagi nyamuk vektor serta belum pernah dilakukan penelitian tentang bioekologi nyamuk vektor di wilayah tersebut maka penelitian ini bertujuan untuk mempelajari keanekaragaman, kepadatan, dan perilaku Anopheles spp, serta menganalisis peta dan karakteristik habitat perkembangbiakan Anopheles spp.

\section{BAHAN DAN METODE}

\section{Lokasi penelitian}

Penelitian dilakukan di Desa Datar Luas, Kecamatan Krueng Sabee, Kabupaten Aceh Jaya,
Provinsi Aceh selama empat bulan (Oktober 2012-Januari 2013).

\section{Penangkapan nyamuk}

Penangkapan nyamuk dewasa dilakukan selama empat malam setiap bulan dengan frekuensi satu minggu. Sebanyak tiga buah rumah dipilih dengan kriteria terdapat penghuni rumah yang positif mengandung parasit, atau dekat dengan habitat potensial Anopheles spp. Jumlah kolektor terdiri atas 6 orang, pada masing-masing rumah ditempatkan dua orang, satu orang di dalam rumah dan satu orang lainnya di halaman rumah. Penangkapan dimulai dari pukul 18:00 06:00 WIB dan dilakukan setiap jam dengan lama penangkapan 40 menit pada metode umpan manusia, dan 10 menit menangkap nyamuk yang istirahat (WHO 1995).

Penangkapan nyamuk dilakukan dengan metode koleksi nyamuk yang hinggap pada umpan manusia (human landing collection) dan nyamuk yang sedang istirahat (resting collection).

\section{Pengumpulan larva}

Larva dikumpulkan menggunakan cidukan plastik bervolume $300 \mathrm{cc}$. Pencidukan dilakukan dengan frekuensi sepuluh kali untuk setiap habitat. Larva yang didapatkan kemudian dimasukkan dalam kantong plastik, dan diberi label sesuai dengan habitatnya. Larva yang terkumpul kemudian dipindahkan ke cawan pemeliharaan larva di dalam kandang nyamuk untuk dipelihara sampai menjadi dewasa agar mudah dilakukan identifikasi. survei larva nyamuk dilakukan sekali selama empat bulan.

\section{Pengukuran karakteristik dan pemetaan habitat Anopheles}

Karakteristik habitat larva Anopheles spp. diperoleh dengan melakukan pengamatan terhadap jenis habitat, kekeruhan, arus air, dasar habitat, keberadaan tanaman air dan predator larva secara visual. Selain itu, dilakukan pengukuran terhadap suhu, $\mathrm{pH}$, salinitas di setiap habitat menggunakan termometer batang $\left({ }^{\circ} \mathrm{C}\right), \mathrm{pH}$ meter digital, refraktometer. Luas habitat diukur dengan menggunakan perkiraan (estimasi), kedalaman habitat dengan cara mencelupkan tongkat kayu ke dalam air lalu diukur dengan meteran sampai 
batas air. Penandaan titik koordinat larva dengan menggunakan GPS Garmin 60.

Pemetaan titik koordinat habitat perkembangbiakan nyamuk Anopheles dianalisis dengan program Arcgis versi 9.1. Dimulai dengan registrasi peta, kemudian digitasi sesuai batas studi, selanjutnya ditransformasi untuk menentukan titik koordinat habitat perkembangbiakan nyamuk Anopheles spp.

\section{Identifikasi nyamuk Anopheles}

Nyamuk dewasa yang berhasil ditangkap selanjutnya diidentifikasi berdasarkan panduan buku Kunci Bergambar Nyamuk Anopheles Dewasa di Sumatera-Kalimantan (Depkes RI 2000).

\section{Analisis data}

Data yang terkumpul dianalisis secara deskriptif dan disajikan dalam bentuk tabel dan grafik. Parameter yang diamati dalam penelitian meliputi kepadatan nyamuk, kelimpahan nisbi, frekuensi nyamuk tertangkap dan dominansi spesies.

Kepadatan nyamuk Anopheles dihitung berdasarkan angka man hour density (MHD) dan man biting rate (MBR). MHD adalah rata-rata nyamuk tertangkap dengan umpan orang per jam, sedangkan MBR adalah rata-rata nyamuk Anopheles tertangkap dengan umpan orang per malam.

Kelimpahan nisbi dihitung dari jumlah individu nyamuk Anopheles spesies tertentu terhadap total jumlah spesies nyamuk yang diperoleh, dan dinyatakan dalam persen.

Frekuensi nyamuk tertangkap dihitung berdasarkan perbandingan antara jumlah penangkapan diperolehnya Anopheles spesies tertentu terhadap jumlah total penangkapan dan dinyatakan dalam persen.

Dominansi spesies (\%) dihitung berdasarkan hasil perkalian antara kelimpahan nisbi dan frekuensi nyamuk tertangkap spesies tersebut dalam satu waktu penangkapan.

Data indeks curah hujan dari BMKG Kabupaten Aceh Jaya dan data kasus penyakit malaria bulanan (MoPI) dari Puskesmas Krueng Sabee selama empat bulan (Oktober 2012-Januari 2013) di uji dengan korelasi pearson dengan kepadatan nyamuk Anopheles per orang/malam (MBR).

\section{HASIL}

\section{Keanekaragaman nyamuk Anopheles}

Terdapat 11 spesies nyamuk Anopheles yang ditemukan dari hasil penangkapan nyamuk dewasa di Desa Datar Luas, yaitu An. kochi, An. barbirostris, An. maculatus, An. letifer, An. tessellatus, An. sinensis, An. vagus, An. separatus, An. sundaicus, An. minimus, dan An. subpictus (Tabel 1).

Jumlah nyamuk yang tertangkap cukup bervariasi. An. kochi merupakan spesies yang paling banyak ditemukan (45,9\%), disusul oleh $A n$. barbirostris dan An. minimus masing-masing 8,1\%. Selain itu, ada enam spesies yang mempunyai persentase yang sama, yaitu An. tessellatus, An. maculatus, An. letifer, An. sinensis, dan An. vagus sebesar 5,4\%. Nyamuk An. sundaicus dan $A n$. subpictus merupakan nyamuk yang paling sedikit ditemukan dalam penelitian ini, masing-masingnya sebesar 2,7\%.

Kelimpahan nisbi nyamuk yang tertinggi adalah An. kochi (43,2\%) dengan frekuensi 0,56\%. Kemudian diikuti An. barbirostris dan An. minimus yang mempunyai nilai yang sama, yaitu $8,1 \%$ dengan frekuensi $0,18 \%$, dan nilai kelimpahan nisbi terendah adalah An. subpictus dengan kelimpahan nisbi 2,7\% dengan frekuensi $0,06 \%$. Nilai dominansi tertinggi juga diperoleh An. kochi (24,19\%), kemudian disusul An. barbirostris dan An. minimus masing-masing 1,46\% (Tabel 2) .

\section{Perilaku menghisap darah nyamuk Anopheles}

Pengamatan perilaku nyamuk Anopheles dalam mengisap darah sangat penting untuk mengetahui spesies yang berpotensi menularkan malaria sehingga dapat menentukan metode pengendalian yang tepat. Kepadatan nyamuk mengisap darah diketahui dari penangkapan dengan human landing collection dan dinyatakan dalam jumlah nyamuk/orang/jam (Tabel 3).

Nyamuk An. kochi merupakan jenis yang sering berkontak dengan orang, baik di dalam maupun di luar rumah dengan total MHD 0,23 nyamuk/orang/ jam, sedangkan An. tessellatus, An. barbirostris, dan An. vagus memiliki kepadatan yang sama, yaitu masing-masingnya 0,04 nyamuk/orang/jam. An. subpictus, An. maculatus, An. minimus, An. sundaicus, dan An. separatus dengan total MHD masing-masingnya 0,02 nyamuk/orang/jam. 
Tabel 1. Persentase jenis nyamuk Anopheles yang tertangkap periode Oktober 2012-Januari 2013 di Desa Datar Luas

\begin{tabular}{|c|c|c|c|c|c|c|c|c|c|}
\hline \multirow{3}{*}{ Spesies } & \multicolumn{8}{|c|}{ Bulan penangkapan } & \multirow{3}{*}{ Total $(\%)$} \\
\hline & \multicolumn{2}{|c|}{ Oktober } & \multicolumn{2}{|c|}{ November } & \multicolumn{2}{|c|}{ Desember } & \multicolumn{2}{|c|}{ Januari } & \\
\hline & DR & LR & DR & LR & DR & LR & DR & LR & \\
\hline Anopheles kochi & 0,0 & 0,0 & 0,0 & 8,1 & 0,0 & 13,5 & 5,4 & 18,9 & 45,9 \\
\hline An. barbirostris & 0,0 & 0,0 & 0,0 & 2,7 & 0,0 & 0,0 & 0,0 & 5,4 & 8,1 \\
\hline An. minimus & 0,0 & 0,0 & 0,0 & 0,0 & 0,0 & 2,7 & 0,0 & 5,4 & 8,1 \\
\hline An. tesselatus & 0,0 & 0,0 & 2,7 & 0,0 & 2,7 & 0,0 & 0,0 & 0,0 & 5,4 \\
\hline An. maculatus & 0,0 & 0,0 & 2,7 & 0,0 & 0,0 & 0,0 & 0,0 & 2,7 & 5,4 \\
\hline An. letifer & 0,0 & 0,0 & 0,0 & 2,7 & 0,0 & 0,0 & 0,0 & 2,7 & 5,4 \\
\hline An. sinensis & 0,0 & 0,0 & 2,7 & 0,0 & 0,0 & 2,7 & 0,0 & 0,0 & 5,4 \\
\hline An. vagus & 0,0 & 0,0 & 0,0 & 0,0 & 0,0 & 2,7 & 2,7 & 0,0 & 5,4 \\
\hline An. separatus & 0,0 & 0,0 & 0,0 & 0,0 & 0,0 & 5,4 & 0,0 & 0,0 & 5,4 \\
\hline An. subpictus & 0,0 & 0,0 & 0,0 & 0,0 & 2,7 & 0,0 & 0,0 & 0,0 & 2,7 \\
\hline An. sundaicus & 0,0 & 0,0 & 0,0 & 0,0 & 0,0 & 0,0 & 2,7 & 0,0 & 2,7 \\
\hline Total (\%) & 0,0 & 0,0 & 8,1 & 13,5 & 5,4 & 27 & 10,8 & 35,1 & 100 \\
\hline
\end{tabular}

DL: dalam rumah; LR: luar rumah.

Tabel 2. Kelimpahan nisbi, frekuensi dan dominansi Anopheles yang tertangkap dengan landing collection di dalam dan di luar rumah di Desa Datar Luas, Oktober 2012-Januari 2013

\begin{tabular}{lccc}
\hline Spesies & Kelimpahan nisbi (\%) & Frekuensi (\%) & Dominansi (\%) \\
\hline Anopheles kochi & 43,2 & 0,56 & 24,19 \\
An. barbirostris & 8,1 & 0,18 & 1,46 \\
An. minimus & 8,1 & 0,18 & 1,46 \\
An. tesselatus & 5,4 & 0,12 & 0,65 \\
An. maculatus & 5,4 & 0,12 & 0,65 \\
An. letifer & 5,4 & 0,12 & 0,65 \\
An. sinensis & 5,4 & 0,12 & 0,65 \\
An. vagus & 5,4 & 0,12 & 0,65 \\
An. separatus & 5,4 & 0,06 & 0,32 \\
An. subpictus & 2,7 & 0,06 & 0,16 \\
An. sundaicus & 2,7 & 0,06 & 0,16 \\
\hline
\end{tabular}

Rata-rata kepadatan nyamuk An. kochi yang ditemukan di luar rumah dengan total MBR 0,10 per orang per malam, sedangkan An. barbirostris dan An. vagus memiliki kepadatan yang sama diluar rumah masing-masing 0,02 per orang per malam. An. minimus dan An. maculatus memiliki rata-rata kepadatan di luar rumah masing-masing 0,01 per orang per malam. Kepadatan nyamuk $A n$. kochi yang ditemukan pada bulan November diluar rumah, yaitu 0,08 per orang per malam, bulan Desember, yaitu 0,12 per orang per malam dan puncak tertinggi ditemukan pada bulan Januari di luar rumah, yaitu 0,21 per orang per malam (Tabel4).

Aktivitas mengisap darah An. kochi terjadi beberapa kali fluktuasi yang tidak begitu teratur. An. kochi mulai mengisap darah dari pukul 23:00-03:00 WIB, dengan puncak aktivitas terjadi pada pukul 00:00-01:00 WIB di luar rumah. $A n$. 142 minimus mulai mengisap darah dari pukul 01:00 03:00 WIB dan diikuti oleh An. barbirostris pada pukul 02:00-03:00 WIB. An. subpictus ditemukan mengisap darah pada pukul 23:00-00:00 WIB, dan pada pukul 02:00-03:00 WIB. Sedangkan $A n$. maculatus dan An. sundaicus juga mempunyai aktivitas mengisap darah yang sama, yaitu pukul 02:00-03:00 WIB. Spesies lain yang juga ditemukan dan mengisap darah manusia meskipun dalam jumlah yang kecil adalah An. tessellatus mengisap darah dari pukul 23:00-01:00 WIB. Sedangkan An. vagus pada pukul 02:00-03:00 WIB dan An. separatus pada pukul 04:00-05:00 WIB. Nyamuk An. sinensis yang juga dikonfirmasi menjadi vektor di Aceh tidak ditemukan mengisap darah manusia dan ditemukan hanya 2 individu dari seluruh populasi nyamuk yang ditangkap (Gambar 1). 
Tabel 3. Kepadatan Anopheles yang mengisap darah (/nyamuk/orang/jam) di Desa Datar Luas, Oktober 2012-Januari 2013

\begin{tabular}{lccccc}
\hline \multirow{2}{*}{ Spesies } & \multicolumn{4}{c}{ Bulan penangkapan } & \multirow{2}{*}{ Total MHD } \\
\cline { 2 - 4 } Anopheles kochi & Oktober & November & Desember & Januari & 0,23 \\
An. tesselatus & 0,00 & 0,04 & 0,06 & 0,12 & 0,04 \\
An. barbirostris & 0,00 & 0,02 & 0,02 & 0,00 & 0,04 \\
An. vagus & 0,00 & 0,00 & 0,00 & 0,04 & 0,04 \\
An.subpictus & 0,00 & 0,00 & 0,02 & 0,02 & 0,02 \\
An. maculatus & 0,00 & 0,00 & 0,02 & 0,00 & 0,02 \\
An. minimus & 0,00 & 0,00 & 0,00 & 0,02 & 0,02 \\
An. sundaicus & 0,00 & 0,00 & 0,02 & 0,00 & 0,02 \\
An. separatus & 0,00 & 0,00 & 0,00 & 0,02 & 0,02 \\
\hline
\end{tabular}

MHD: man hour density.

Tabel 4. Rata-rata kepadatan Anopheles yang mengisap darah orang per malam (man biting rate) di Desa Datar Luas, Oktober 2012-Januari 2013

\begin{tabular}{|c|c|c|c|c|c|c|c|c|c|c|}
\hline \multirow{3}{*}{ Spesies } & \multicolumn{8}{|c|}{ Bulan penangkapan } & \multirow{2}{*}{\multicolumn{2}{|c|}{ Rata-rata MBR }} \\
\hline & \multicolumn{2}{|c|}{ Oktober } & \multicolumn{2}{|c|}{ November } & \multicolumn{2}{|c|}{ Desember } & \multicolumn{2}{|c|}{ Januari } & & \\
\hline & $\mathrm{DR}$ & LR & DR & LR & $\mathrm{DR}$ & LR & $\mathrm{DR}$ & LR & DR & LR \\
\hline Anopheles kochi & 0,00 & 0,00 & 0,00 & 0,08 & 0,00 & 0,12 & 0,04 & 0,21 & 0,01 & 0,10 \\
\hline An. barbirostris & 0,00 & 0,00 & 0,00 & 0,00 & 0,00 & 0,00 & 0,00 & 0,08 & 0,00 & 0,02 \\
\hline An. vagus & 0,00 & 0,00 & 0,00 & 0,00 & 0,00 & 0,04 & 0,00 & 0,04 & 0,00 & 0,02 \\
\hline An. tesselatus & 0,00 & 0,00 & 0,04 & 0,00 & 0,04 & 0,00 & 0,00 & 0,00 & 0,02 & 0,00 \\
\hline An. minimus & 0,00 & 0,00 & 0,00 & 0,00 & 0,00 & 0,04 & 0,00 & 0,00 & 0,00 & 0,01 \\
\hline An. maculatus & 0,00 & 0,00 & 0,00 & 0,00 & 0,00 & 0,00 & 0,00 & 0,04 & 0,00 & 0,01 \\
\hline An.subpictus & 0,00 & 0,00 & 0,00 & 0,00 & 0,04 & 0,00 & 0,00 & 0,00 & 0,01 & 0,00 \\
\hline An. sundaicus & 0,00 & 0,00 & 0,00 & 0,00 & 0,00 & 0,00 & 0,04 & 0,00 & 0,01 & 0,00 \\
\hline An. separatus & 0,00 & 0,00 & 0,00 & 0,00 & 0,00 & 0,04 & 0,00 & 0,00 & 0,00 & 0,00 \\
\hline
\end{tabular}

DR: dalam rumah; LR: luar rumah; MBR: man biting rate.

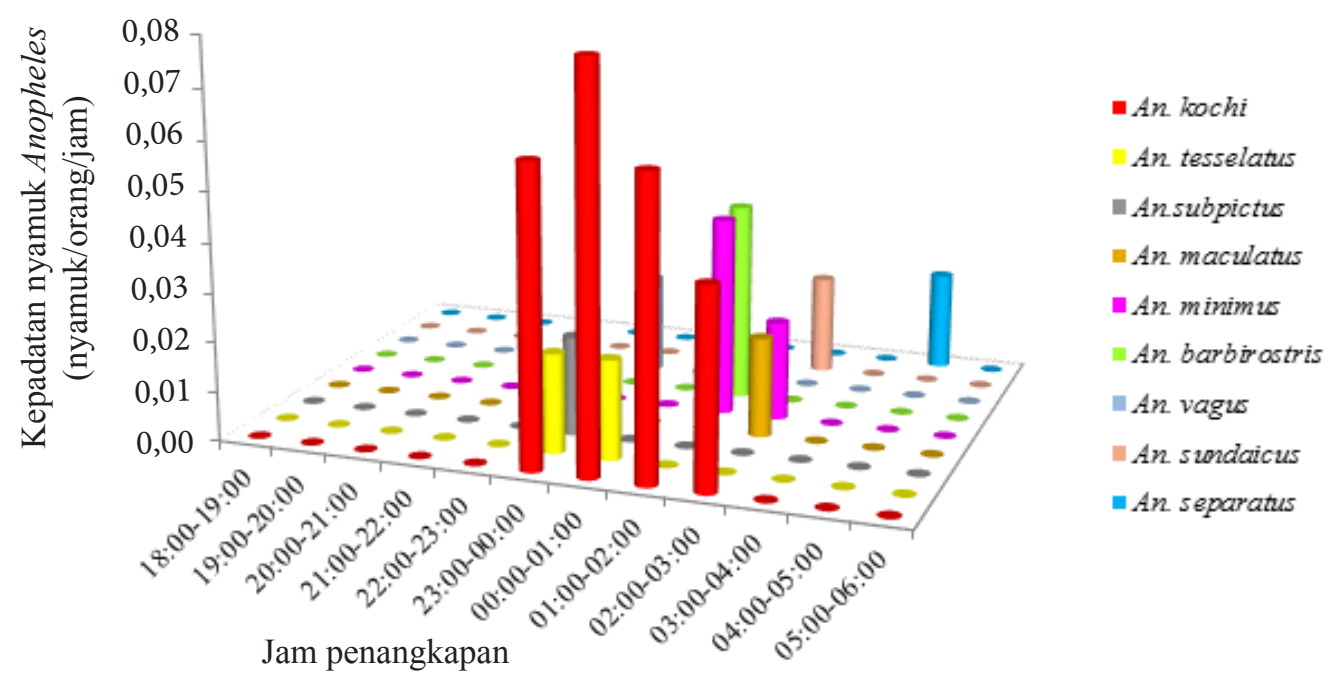

Gambar 1. Aktifitas Anopheles mengisap darah (/nyamuk/orang/jam) di Desa Data Luas dari Oktober 2012-Januari 2013. 
Berdasarkan hasil uji statistik menunjukkan hubungan yang tidak erat $\mathrm{r}=0,13$ dengan $(\mathrm{R}=$ $0,131)$. Artinya, kasus malaria yang terjadi belum tentu karena nyamuk An. kochi yang ditemukan di Desa Datar Luas. Berdasarkan data dari puskesmas Krueng Sabee penderita yang terkena malaria semuanya berumur diatas 15 tahun sehingga agens penyakit mungkin dibawa oleh penderita dari luar.

Hasil uji statistik menunjukkan hubungan yang tidak erat $r=0,05$ dengan $(P>0,05)$ sehingga dapat dikatakan curah hujan tidak mempengaruhi kepadatan nyamuk An. kochi yang ada di Desa Datar Luas. Data curah hujan yang digunakan merupakan data sekunder yang diperoleh dari BMKG Aceh Jaya.

\section{Karakteristik habitat Anopheles}

Di Desa Datar Luas terdapat 22 perairan yang diperkirakan merupakan habitat perkembangbiakan Anopheles spp. Perairan tersebut dapat dikelompokkan menjadi 6 tipe perairan, yaitu kolam $(40,91 \%)$, genangan air hujan $(22,72 \%)$, rawa-rawa $(13,64 \%)$, parit $(13,64 \%)$, sumur tua $(4,55 \%)$, dan bekas tapak ban (4,55\%). Dari 6 tipe habitat tersebut hanya 4 tipe habitat yang diketahui sebagai habitat perkembangbiakan Anopheles spp., yaitu kolam, genangan air hujan, rawa-rawa dan sumur tua.

\section{Pemetaan habitat potensial perkembangbiakan larva Anopheles}

Dari 4 tipe perairan yang positif larva Anopheles, diketahui bahwa larva An. kochi, An. aconitus, dan An. vagus dapat ditemukan di rawa-rawa dengan kepadatan 0,20 larva/cidukan, larva $A n$. separatus ditemukan di sumur tua dengan kepadatan 0,10 larva/cidukan, larva $A n$. barumbrosus dan An. kochi ditemukan di genangan air hujan serta An. letifer ditemukan di kolam dengan kepadatan 0,20 larva/cidukan (Gambar 2).

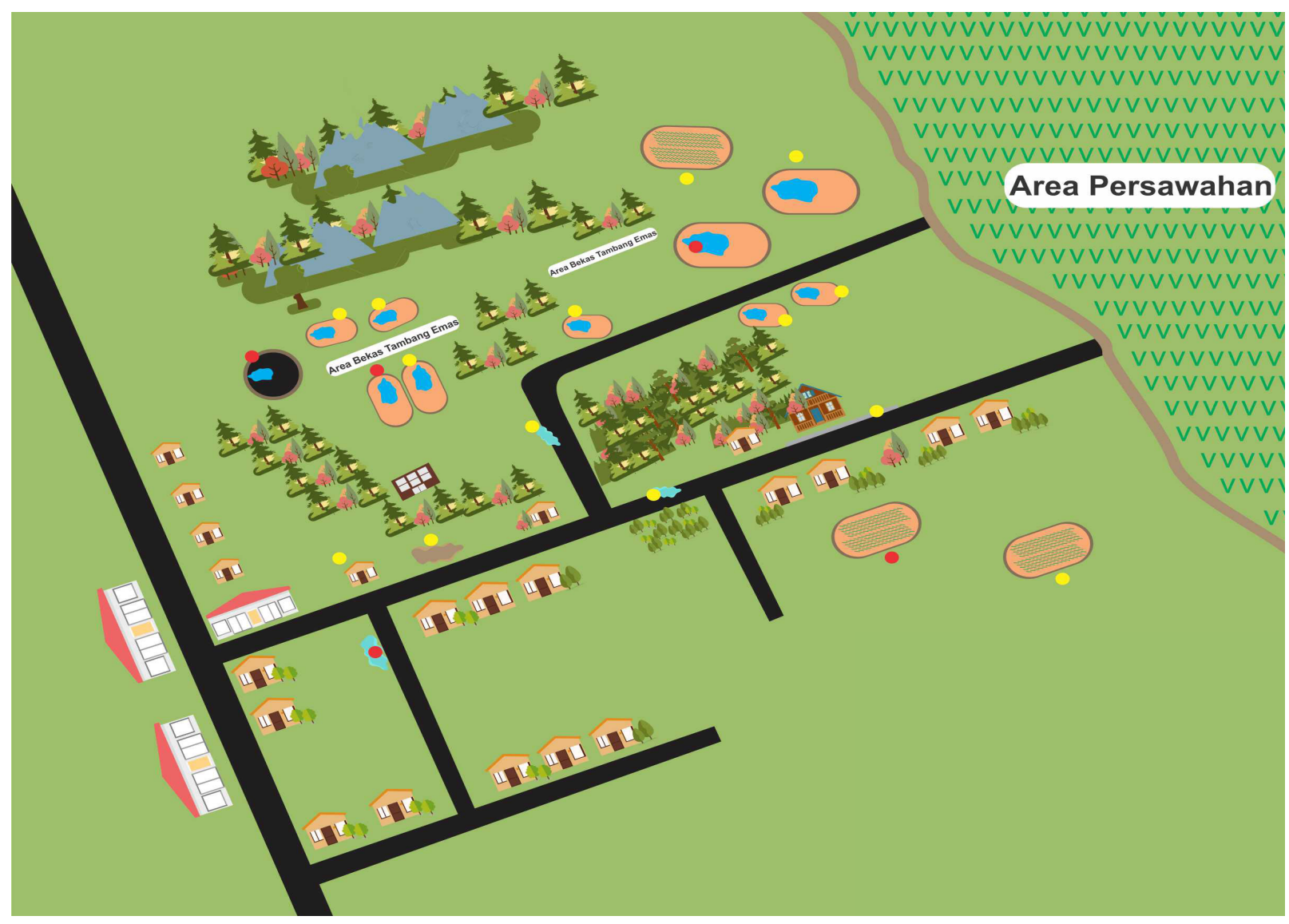

Gambar 2. Denah keberadaan 6 habitat nyamuk Anopheles spp $(\square$ : rawa; $@$ : kolam bekas galian atau kolam kering; __ : genangan air; _ : selokan/got; - : sumur bekas galian; _ : bekas tapak ban) di Desa Datar Luas, Kecamatan Krueng Sabee, Kabupaten Aceh Jaya, Oktober 2012Januari 2013. 


\section{PEMBAHASAN}

Dari hasil penelitian di Desa Datar Luas diperoleh 11 spesies nyamuk yang merupakan nyamuk oriental Sumatera-Jawa, hal ini juga sama dengan beberapa penemuan vektor Anopheles di Sumatera dan Kalimantan serta Jawa yang merupakan wilayah oriental sehingga akan didapatkan beberapa spesies Anopheles yang sama. Hasil penelitian Barodjie et al. (2007) di Kabupaten Pekalongan (Jawa) mendapatkan empat spesies Anopheles yang sama (An. barbirostris, An. kochi, An. maculatus, dan An. vagus) dari enam spesies yang dijumpai di Desa Datar Luas. Sedangkan penelitian Syafruddin et al. (2010) di Lampung Selatan (Sumatera) terdapat tujuh spesies Anopheles yang sama dengan yang dijumpai peneliti di wilayah Desa Datar Luas, Aceh Jaya, yaitu An. barbirostris, An. kochi, An. minimus, An. subpictus, An. sundaicus, An. tessellatus, dan An. vagus, sedangkan Noor (2002) menemukan lima spesies Anopheles yang sama dengan nyamuk di Desa Datar Luas, Aceh Jaya, yaitu An. barbirostris, An. kochi, An. maculatus, An. minimus, An. subpictus, dan An. Vagus di Desa Sedayu Kabupaten Pueworejo (Jawa).

Nyamuk sangat lokal spesifik, untuk melangsungkan kehidupannya larva dan nyamuk Anopheles spp. memerlukan kondisi yang sesuai karakteristik habitat perkembangbiakannya termasuk mikro klimatnya. Oleh karena itu, walaupun termasuk wilayah oriental, tetapi di wilayah penelitian, yaitu Desa Datar Luas, Aceh Jaya tidak semua spesies nyamuk oriental dapat ditemukan secara lengkap, seperti juga yang ditemukan oleh peneliti-peneliti lain. Ada keterbatasan sehingga hanya Anopheles spp. tertentu yang bisa hidup di wilayah tertentu, seperti halnya nyamuk Anopheles spp. di Desa Datar Luas.

Berdasarkan hasil penangkapan nyamuk selama empat bulan di Desa Datar Luas, nyamuk Anopheles paling banyak tertangkap di luar rumah dari pada di dalam rumah. Hal ini menunjukkan bahwa, nyamuk Anopheles yang ada di desa ini lebih banyak mengisap darah manusia yang berada di luar rumah (eksofagik) daripada di dalam rumah (endofagik). Hal yang sama juga ditemukan terhadap An. kochi yang mempunyai sifat eksofagik di Sumatera Utara dan Banjarnegara (Idram et al. 2002; Widiastuti et al. 2006). Selain itu, hasil penelitian Idram et al. (2002) di Mandailing Natal Sumatera utara juga didapatkan An. nigerrimus, An. sundaicus, dan An. kochi merupakan spesies yang paling dominan, sedangkan An. sinensis, An. umbrosus, An. separatus, An. lestiparaliae, An. barbirostris, An. tessellatus, dan An. maculatus merupakan spesies yang tidak dominan. Nyamuk Anopheles yang tertangkap di Desa Datar Luas memiliki keanekaragaman yang tidak jauh berbeda dengan nyamuk Anopheles yang tertangkap di Kabupaten Jepara, Jawa Tengah, yaitu An. aconitus, An. annularis, An. barbirostris, An. indefinitus, An. kochi, An. maculatus, An. minimus, An. subpictus, An. tessellatus, dan An. vagus dengan nilai dominansi tertinggi dimiliki oleh An. aconitus yang mengisap darah orang baik di dalam maupun di luar rumah, sedangkan An. maculatus dan An. subpictus tidak memiliki nilai dominansi (Barodji et al. 1992). Sedangkan di Desa Pinamula Kecamatan Momunu Kabupaten Buol Chadijah et al. (2010) menyatakan nyamuk An. barbirostris merupakan spesies yang paling dominan, kemudian diikuti An. tesselatus, An. vagus, An. peditaeniatus, An. kochi, An. sinensis, dan An. montanus.

Udin (2005) menyatakan di Desa Segara Kembang, Sumatera Selatan An. kochi menunjukkan fluktuasi mengisap darah pada pukul 20:0022:00 WIB, An. barbirostris dari pukul 18:0002:00 dengan puncaknya pada pukul 00:00 WIB. Munif et al. (2008) juga melaporkan di Kabupaten Sukabumi An. vagus mempunyai puncak aktivitas mengisap darah tertinggi pada pukul 00:00pukul 01:00 WIB, An. aconitus dengan puncak mengisap darah pada pukul 22:00-23:00 WIB, An. barbirostris pada pukul 19:00-20:00 WIB, dan An. maculatus pada pukul 19:00-20:00 dan meningkat kembali pada pukul 02:00-03:00 WIB, serta An. kochi yang tidak ditemukan mengisap darah manusia. Amirullah (2012) juga menyatakan di Kabupaten Halmahera Selatan An. kochi memiliki puncak aktivitas mengisap darah terjadi antara pukul 20:00-22:00 kemudian menurun hingga pukul 04:00-05:00, aktivitas kembali meningkat pada pukul 05:00-06:00.

An. kochi diduga menjadi vektor potensial di Desa Datar Luas berdasarkan hasil kepadatan nyamuk yang diperoleh. Kepadatan An. kochi per 
orang per malam (MBR) dari bulan Oktober 2012Januari 2013 dihubungkan dengan angka MoPI pada bulan yang sama. Indeks curah hujan selama penelitian sangat fluktuatif dan dihubungkan dengan kepadatan nyamuk An. kochi yang mengisap darah orang per orang per malam (MBR). Munif et al. (2007) di Desa Lengkong Sukabumi menyatakan An. barbirostris merupakan spesies yang mempunyai kepadatan tertinggi sebesar 2,47 nyamuk/orang/jam, diikuti An. aconitus 2,00 nyamuk/orang/jam, An. maculatus 0,47 nyamuk/ orang/jam dan yang paling sedikit An. tesselatus 0,04 nyamuk/orang/jam. Kondisi ini sangat berbeda dengan hasil penelitian di Desa Datar Luas yang menyatakan An. kochi merupakan spesies Anopheles dengan kepadatan tertinggi.

Karakteristik habitat Anopheles yang terdapat di Desa Datar Luas merupakan habitat perkembangbiakan larva An. letifer yang ditemukan di kolam, sedangkan Anopheles jenis lainnya tidak ditemukan di kolam tersebut. Kolamkolam ini merupakan kolam bekas pengolahan tambang emas yang sudah tidak dipergunakan lagi sehingga terbengkalai dan menjadi habitat nyamuk. Kolam tersebut terletak pada areal terbuka di wilayah pemukiman penduduk, tanaman yang terdapat disekitar kolam adalah pakis, rumputrumput liar, keladi dan lumut. Predator yang ada di kolam tersebut terdiri atas berudu, ikan kecil, dan udang. Luasan kolam berkisar dengan rata-rata $2,58 \mathrm{~m} \times 1,85 \mathrm{~m}$, sifat airnya tidak mengalir, dan kedalamannya berkisar antara 40-140 cm dengan dasar habitat semen dan tanah lumpur. Suwardi (2012) melaporkan di Desa Riau Silip Provinsi Bangka Belitung habitat positif larva An. letifer yang ditemukan di kubangan tidak ditemukan tanaman air pada permukaan air, tetapi di sekitar habitat terdapat pohon yang dapat berguna sebagai naungan. Setyaningrum et al. (2008) juga melaporkan di Desa Way Muli, Kecamatan Rajabasa Provinsi Lampung Selatan, tumbuhan yang hidup disekitar perairan tempat perkembangbiakan larva Anopheles spp. didominasi oleh tumbuhan berkayu, seperti bandotan (Ageratum conizoides), bakau (Avicinnea sp.), kelapa (Cocos nucifera), dan pohon pisang (Musa paradiciaca). Selain itu, Rahmawati (2010) di Desa Lifuleo Kabupaten Kupang juga menyatakan larva
Anopheles spp. ditemukan pada perairan dangkal yang dinaungi tumbuhan semak dan pohon waru.

Rawa-rawa di Desa Datar Luas merupakan genangan air yang luas yang selalu tergenang air dan berdekatan dengan pemukiman penduduk serta ditumbuhi banyak vegetasi tanamantanaman liar, seperti rumput liar, rumput gajah, keladi, rumpun bambu dan semak-semak dengan kerapatan tanaman yang tinggi. Larva Anopheles di rawa-rawa ditemukan berlindung di bawah semak-semak dan serasah daun bambu kering. Predator yang terdapat di rawa-rawa adalah ikan kecil, dan larva capung. Dasar habitatnya berupa lumpur dengan rata-rata luasannya 5,36 m x 9,6 m, sifat airnya tidak mengalir dan kedalamannya berkisar antara 10-27 cm. Mardiana et al. (2007) menyatakan, di Kecamatan Sumur Kabupaten Pandeglang ditemukan kobakan bekas kubangan kerbau yang telah lama tidak digunakan sehingga terlantar bila musim hujan dan digenangi oleh air, di sekitar kobakan ditumbuhi tanaman semak belukar dengan kedalaman air $10 \mathrm{~cm}$ dan positif ditemukan larva An. kochi dan An. vagus.

Sumur yang tidak dimanfaatkan lagi dan terbengkalai dapat berpotensi menjadi habitat potensial untuk perkembangbiakan nyamuk Anopheles. Pada sumur tua tersebut dibagian dindingnya banyak ditumbuhi lumut dan rumputrumput liar, selain itu juga didapatkan predator berupa berudu dan ikan kecil. Luasan sumur tersebut adalah $3 \mathrm{~m} \times 4 \mathrm{~m}$, dengan kedalaman lebih dari $500 \mathrm{~cm}$. Jenis larva Anopheles yang ditemukan di sumur tua adalah An. separatus.

Genangan air hujan merupakan lekukan pada tanah yang hanya berisi air pada waktu hujan dan tidak berbentuk permanen, dengan rata-rata luasan $3,04 \mathrm{~m} \times 1,05 \mathrm{~m}$. Jenis tanaman yang hidup di sekitar genangan air hujan adalah rumput, lumut, dan eceng gondok.

Parit merupakan lubang memanjang yang berada di permukaan tanah yang dibuat dengan sengaja oleh manusia untuk mengalirkan air. Di Desa Datar Luas tidak ditemukan habitat positif larva Anopheles yang berada di parit. Kondisi parit di desa ini ada yang jernih dan keruh serta tidak mengalir. Jenis tanaman di sekitar parit adalah rumput-rumput liar, lumut, tanaman liar, dan pakis. Kedalaman berkisar antara 13-15 cm. 
Tidak ditemukan larva di parit diperkirakan karena kurangnya vegetasi tanaman yang ada di parit dan banyaknya predator larva.

Bekas tapak ban merupakan genangan air yang berasal dari air hujan yang tertampung di sebuah lekukan yang diakibatkan oleh kendaraan yang melintasi areal tersebut dan bersifat tidak permanen. Di Desa Datar Luas tidak ditemukan habitat positif larva Anopheles di bekas tapak ban. Jenis tanaman yang berada di sekitar lekukan tapak ban adalah rumput dan lumut. Luasannya adalah $1,10 \mathrm{~m} \times 1,0 \mathrm{~m}$, dengan kedalaman $2 \mathrm{~cm}$. Tidak ditemukan larva Anopheles spp. pada jejak ban mobil diperkirakan karena seringnya jalan tersebut dilewati kendaraan.

Habitat potensial larva An. letifer yang ditemukan di Desa Datar Luas letaknya tidak jauh dari pemukiman penduduk sekitar 300 meter, yang merupakan tempat kolam-kolam bekas pengolahan emas dari pertambangan yang tidak aktif lagi. Habitat potensial larva $A n$. kochi, An. aconitus, dan An. vagus ditemukan di rawa-rawa yang berjarak sekitar 150 meter dari pemukiman penduduk. Habitat potensial larva $A n$. separatus ditemukan pada sumur tua di sekitar kolam yang juga mempunyai jarak sekitar $250 \mathrm{~m}$ dari pemukiman penduduk. Selain itu, larva $A n$. barumbrosus dan An. kochi juga di temukan pada habitat yang semipermanen, seperti genangan air hujan yang berada di sekitar badan jalan yang berjarak sekitar 100 meter dari pemukiman penduduk. Penemuan habitat perkembangbiakan larva Anopheles di sekitar pemukiman penduduk cenderung menyebabkan Desa Datar Luas berisiko untuk tertular penyakit malaria. Keterkaitan antara jarak habitat dengan rumah penderita malaria dengan tiga zona risiko, yaitu radius $0-100 \mathrm{~m}$ merupakan zona risiko tinggi, radius antara 100 $200 \mathrm{~m}$ merupakan zona risiko sedang, dan radius 200-300 m merupakan zona kurang berisiko (Boewono \& Ristiyanto 2004).

\section{KESIMPULAN}

Di Desa Datar Luas ditemukan sebelas spesies Anopheles, yaitu An. kochi, An. barbirostris, An. maculatus, An. letifer, An. tesellatus, An. sinensis, An.vagus, An. separatus,
An. sundaicus, An. minimus, dan An. subpictus. An. kochi merupakan Anopheles yang paling dominan dan cenderung mengisap darah di luar rumah (eksofagik) dan beristirahat di luar rumah (eksofilik) dengan puncak fluktuasi menghisap darah terjadi pada pukul 00:00-01:00 WIB. Terdapat 22 habitat potensial larva Anopheles yang terdiri atas empat tipe habitat, yaitu kolam, rawa-rawa, sumur tua, dan genangan air hujan.

\section{UCAPAN TERIMA KASIH}

Terima kasih disampaikan kepada Mahasiswa Pascasarjana Program Studi Parasitologi dan Entomologi Kesehatan angkatan 2011 (Supriyono, Resa Pratomo, Nissa, Siti, Zahara, dan Dewi Djungu), yang telah membantu selama penelitian ini berlangsung hingga proses penulisan.

\section{DAFTAR PUSTAKA}

Amirullah. 2012. Studi Bioekologi Anopheles spp. Sebagai Dasar Penyusunan Strategi Pengendalian Vektor Malaria di Kabupaten Halmahera Selatan Provinsi Maluku Utara. Disertasi. Bogor: Institut Pertanian Bogor.

Barodji, Boewono DT, Suwasono H. 1992. Fauna Anopheles di daerah endemis malaria Kabupaten Jepara Jawa Tengah. Buletin Penelitian Kesehatan 20:34-42.

Barodji, Boewono DT, Sumardi. 2007. Fauna nyamuk, konfirmasi vektor dan beberapa aspek bionomik vektor malaria di daerah endemis malaria Kabupaten Pekalongan. Jurnal Ekologi Kesehatan 6:549-559.

Becker N, Petric D, Zgomba M, Boase C, Dahl C, Lane J, Kaiser A. 2003. Mosquito And Their Control. New York: Kluwer Academic/Plenum Publisher.

Boewono DT, Ristiyanto. 2004. Studi bioekologi vektor malaria di Kecamatan Srumbung Kabupaten Magelang, Jawa Tengah. Dibawakan dalam Simposium Nasional I Hasil-Hasil Litbangkes 2004.

Chadijah S, Veridiana NN, Kurniawan A. 2010. Konfirmasi nyamuk Anopheles sebagai vektor malaria dengan Elisa di Desa Pinamula Kecamatan Momunu Kabupaten Buol. Jurnal Vektor Penyakit 4:1-8. 
[Depkes RI] Departemen Kesehatan RI. 2000. Kunci Bergambar Nyamuk Anopheles Dewasa di Sumatera-Kalimantan. Jakarta: Depkes RI.

[Dinkes Prov. Aceh] Dinas Kesehatan Provinsi Aceh. 2011. Laporan Bulanan Penemuan Dan Pengobatan Malaria. Banda Aceh: Dinkes Prov. Aceh.

Idram N S I, Sudomo M, Djana I G W, Empi S. 2002. Fauna Anopheles di Tapanuli Selatan dan Mandailing Natal, Sumatera Utara. Buletin Peneliti Kesehatan 30:161-172.

[Kemenkes RI] Kementerian Kesehatan RI. 2011. Epidemiologi Malaria Di Indonesia. Jakarta: Kemenkes RI.

Mardiana, Sukowati S, Wigati R A. 2007. Beberapa Aspek perilaku nyamuk Anopheles sundaicus di Kecamatan Sumur, Kabupaten Pandeglang. Buletin Penelitian Kesehatan 6:624-630.

Munif A, Sudomo M, Soekirno. 2007. Bionomi Anopheles spp. Di Daerah Endemis Malaria Kecamatan Lengkong, Sukabumi. Buletin Penelitian Kesehatan 35:57-80.

Munif A, Rusmiarto S, Aryati Y, Andris H, Stoops C A. 2008. Konfirmasi Status Anopheles sebagai vektor pendamping saat kejadian luar biasa malaria di Kabupaten Sukabumi Indonesia. Jurnal Ekologi Kesehatan 7:689-696.

Noor E. 2002. Studi Komunitas Nyamuk Anopheles Di Desa Sedayu Kecamatan Loano Kabupaten Purworejo Jawa Tengah. Tesis. Bogor: Institut Pertanian Bogor.
Rahmawati E. 2009. Keragaman Jenis, Perilaku dan Habitat Anopheles spp. Di Desa Lifuleo Kecamatan Kupang Barat Kabupaten Kupang, Nusa Tenggara Timur. Tesis. Bogor: Institut Pertanian Bogor.

Setyaningrum E, Mulyani S, Rosa E, Andananta K. 2008. Studi ekologi perkembangbiakan nyamuk vektor malaria di Desa Way Muli, Kecamatan Rajabasa Lampung Selatan. Di dalam: Seminar Hasil Penelitian \& Pengabdian Masyarakat. pp. 292-229. Lampung: Universitas Lampung.

Suwardi. 2011. Perilaku Dan Karakteristik Habitat Nyamuk Anopheles spp. Di Desa Riau Kecamatan Riau Silip Kabupaten Bangka Provinsi Bangka Belitung. Tesis. Bogor: Institut Pertanian Bogor. Syafruddin D, Hidayati APN, Asih PBS, Hawley WA, Sukowati S, Lobo NF. 2010. Detection of 1014F kdr mutation in four major Anophelinae malaria vektors in Indonesia. Malaria Journal 9:1-8.

Udin. 2005. Studi Perilaku Mengisap Darah, Anopheles spp. di Desa Segara Kembang Kecamatan Lengkiti Kabupaten Ogankomering Ulu (Oku) Sumatera selatan. Tesis. Bogor: Institut Pertanian Bogor.

[WHO] World Health Organization. 1995. Vektor Control For Malaria and Other Mosquito-Borne Disease. Geneva: WHO.

Widiastuti D, Yunianto B, Ikawati. 2006. Keanekaragaman jenis nyamuk Anopheles di daerah dengan atau tanpa kebun salak di Kabupaten Banjarnegara. Balaba 2:12-14. 